\title{
Pembelajaran interaktif berbasis android meningkatkan kemandirian belajar dan hasil belajar SMK negeri 2 Selong Kabupaten Lombok Timur
}

\author{
Muh. Khairurrozikin, Madziatul Churiyah* \\ Universitas Negeri Malang, Jl. Semarang No. 5 Malang, Jawa Timur, Indonesia \\ *Penulis korespondensi, Surel: madziatul.churiyah.fe@um.ac.id
}

Paper received: 3-5-2021; revised: 24-5-2021; accepted: 28-5-2021

\begin{abstract}
Abstrak
Pembelajaran di era globalisasi seperti sekarang ini sangat bergantung pada kemajuan teknologi, terlebih di masa pandemi Covid-19. Salah satu komponen yang berperan penting dalam pembelajaran adalah media pembelajaran. Sehingga guru dituntut untuk memiliki tingkat kreativitas dan inovasi yang tinggi dalam mengembangkan media pembelajaran. Oleh karena itu penelitian ini bertujuan untuk menghasilkan produk berupa media pembelajaran berbasis Android menggunakan Articulate Storyline 3 untuk meningkatkan kemandirian belajar dan hasil belajar peserta didik. Media pembelajaran yang dikembangkan memuat segala fungsi dalam kegiatan pembelajaran, mulai dari kegiatan pendahuluan, materi pembelajaran, soal latihan, sampai dengan soal evaluasi, selain penyajian materi yang berupa tulisan juga disajikan materi berupa e-book dan video pembelajaran. Penelitian ini menggunakan metode penelitian dan pengembangan (R\&D) Borg and Gall yang telah dimodifikasi. Teknik analisis data yang digunakan adalah teknik analisis deskriptif persentase. Hasil penelitian dan pengembangan ini adalah media pembelajaran interaktif berbasis Android menggunakan Articulate Storyline 3 pada mata pelajaran Korespondensi yang diberi nama Me-Better yang telah dinyatakan valid serta layak untuk diimplementasikan pada kegiatan pembelajaran berdasarkan validasi ahli materi, ahli media, dan uji coba kelompok kecil, serta telah terbukti dapat meningkatkan kemandirian belajar dan hasil belajar peserta didik, hal tersebut berdasarkan uji coba yang dilakukan terhadap peserta didik pada kelas kontrol dan kelas eksperimen. Sehingga dapat disimpulkan bahwa media pembelajaran Me-Better dinilai layak dan efektif untuk diimplementasikan sebagai media pembelajaran untuk meningkatkan kemandirian belajar dan hasil belajar peserta didik pada mata pelajaran korespondensi.
\end{abstract}

Kata kunci: media pembelajaran interaktif; korespondensi; android; articulate storyline 3

\section{Pendahuluan}

Sejak tahun 2020 sampai dengan saat ini pandemi Covid-19 masih menyerang semua belahan dunia, tidak terkecuali, untuk mencegah penularan yang lebih luas khususnya di bidang pendidikan, Kemendikbud melalui Surat Edaran Nomor 4 Tahun 2020 menghimbau untuk proses belajar mengajar menerapkan pembelajaran jarak jauh secara daring. Pembelajaran secara daring merupakan pemanfaatan jaringan internet dalam proses pembelajaran (Dewi, 2020). Selama pembelajaran jarak jauh tentu dibutuhkan alat bantu yang dapat membantu tercapainya tujuan pembelajaran, salah satu alat bantu dalam kegiatan pembelajaran adalah media pembelajaran. Media pembelajaran sendiri merupakan segala sesuatu yang dipergunakan untuk memberikan rangsangan pada pikiran, perasaan, perhatian dan kemampuan atau keterampilan para peserta didik sehingga dapat mendorong terjadinya proses belajar (Ekayani, 2017).

Pada dasarnya media pembelajaran sangat beraneka ragam baik macam maupun jenisnya. Seperti yang dikemukakan oleh Susilana dan Riyana (2009) media pembelajaran dapat diklasifikan menjadi berbagai macam mulai dari media cetak, media audio, media video, 
multimedia dan sebagainya. Media pembelajaran yang banyak digandrungi saat ini adalah media pembelajaran berbasis elektronik. Salah satu software yang biasa digunakan untuk membuat media pembelajaran interaktif berbasis android adalah Articulate Storyline 3. Articulate storyline 3 merupakan aplikasi yang dapat dijadikan sebagai media untuk presentasi dan menyampaikan informasi (Yahya, 2020). Aplikasi Articulate Storyline 3 sangat cocok digunakan untuk membuat media pembelajaran, karena sangat mudah untuk dioperasikan, dan tidak memerlukan bahasa pemrograman sehingga mudah dioperasikan oleh guru.

Berdasarkan hasil wawancara yang dilakukan dengan Bapak Sabri, S.Pd. selaku Waka Kurikulum SMK Negeri 2 Selong Kabupaten Lombok Timur. Keadaan seperti sekarang ini yang harus melaksanakan pembelajaran dari rumah masing-masing tentunya sangat sulit untuk mengontrol para peserta didik, dan dibutuhkan kemandirian peserta didik dalam melakukan pembelajaran. Menurut Bapak Sabri dibutuhkan adanya peningkatan kemandirian belajar peserta didik, agar pembelajaran jarak jauh bisa lebih optimal dan setara dengan pembelajaran secara langsung di sekolah. Selain itu juga diperlukan peningkatan hasil belajar mengingat masih terdapat peserta didik yang nilainya di bawah rata-rata KKM. Berdasarkan uraian fakta diatas maka peneliti menawarkan solusi dengan cara membuat media pembelajaran interaktif berbasis Android pada mata pelajaran korespondensi yang dapat dioperasikan melalui smartphone peserta didik sehingga mudah diakses kapan saja dan dimana saja.

\section{Metode}

Model penelitian dan pengembangan yang digunakan pada penelitian ini adalah model R\&D oleh Borg and Gall yang dimodifikasi dan disesuaikan dengan kebutuhan peneliti menjadi 5 langkah seperti pada gambar berikut ini.

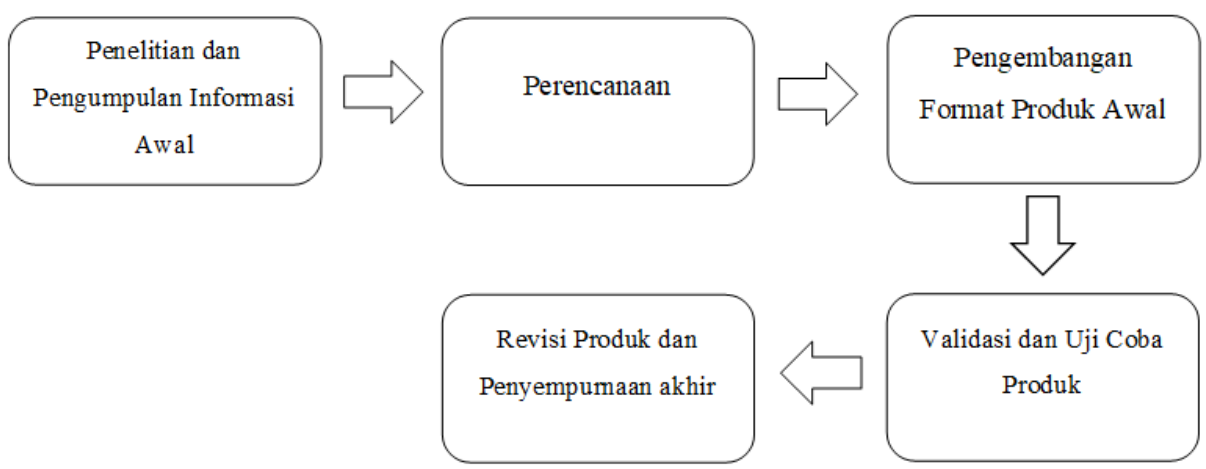

Gambar 1. Prosedur Penelitian dan Pengembangan

Langkah pertama adalah peneliti melakukan penelitian dan pengumpulan informasi awal, hal ini dilakukan untuk mengetahui kebutuhan media pembelajaran di lokasi penelitian dan yang sesuai dengan tuntutan saat ini. Langkah kedua adalah tahap perencanaan yang meliputi pembuatan desain aplikasi, penyusunan menu-menu yang ada pada Me-Better, kelengkapan materi pembelajaran dan jenis evaluasi yang akan diterapkan pada Me-Better. Langkah ketiga adalah pengembangan format produk awal, pada tahap ini dilakukan pengumpulan bahan-bahan pengembangan, pengolahan bahan, serta proses pengembangan produk. Langkah keempat adalah validasi dan uji coba produk, validasi produk dilakukan oleh seorang validator ahli materi, dan seorang validator ahli media, setelah itu dilakukan uji coba kelompok kecil terhadap 6 orang peserta didik, kemudian uji coba kelompok besar. Langkah 
terakhir adalah revisi dan penyempurnaan akhir produk, pada tahap ini dilakukan revisi terhadap produk berdasarkan masukan dari validator ahli dan subjek uji coba.

Terdapat dua jenis data yang diperoleh pada penelitian ini, data kualitatif dan data kuantitatif. Data kuantitatif terdiri atas data hasil validasi ahli materi, data hasil validasi ahli media, data hasil uji coba kelompok kecil, dan data kemandirian belajar serta data hasil belajar peserta didik. Sedangkan data kualitatif diperoleh dari masukan, kritik serta saran dari ahli media, ahli materi, subjek uji coba kelompok kecil. Data yang diperoleh selanjutnya dianalisis menggunakan analisis deskriptif persentase untuk mengukur tingkat efektivitas dan kelayakan media pembelajaran yang dikembangkan.

\section{Hasil dan Pembahasan}

Produk yang dihasilkan pada penelitian dan pengembangan ini adalah Mobile Education for Business Letter (Me-Better) pada mata pelajaran korespondensi untuk kelas X Otomatisasi dan Tata Kelola Perkantoran. Media pembelajaran ini berbasis Android yang dikembangkan menggunakan software Articulate Storyline 3. Media pembelajaran Me-Better ini terdiri dari beberapa menu yang diuraikan pada Gambar berikut ini.

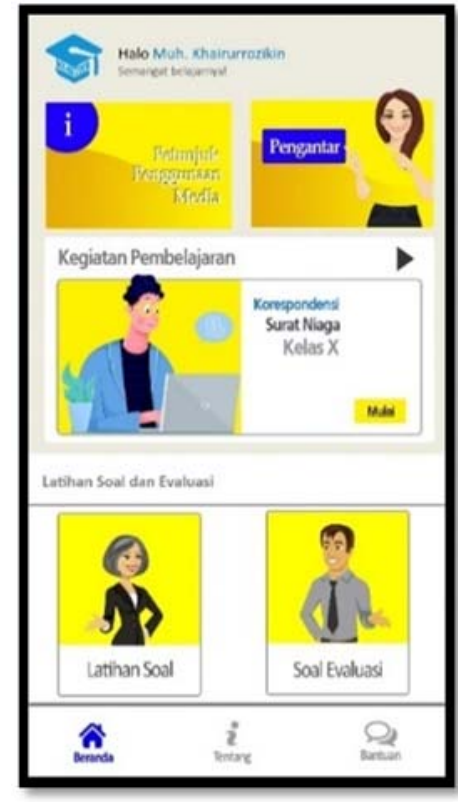

Gambar 3. Tampilan Beranda

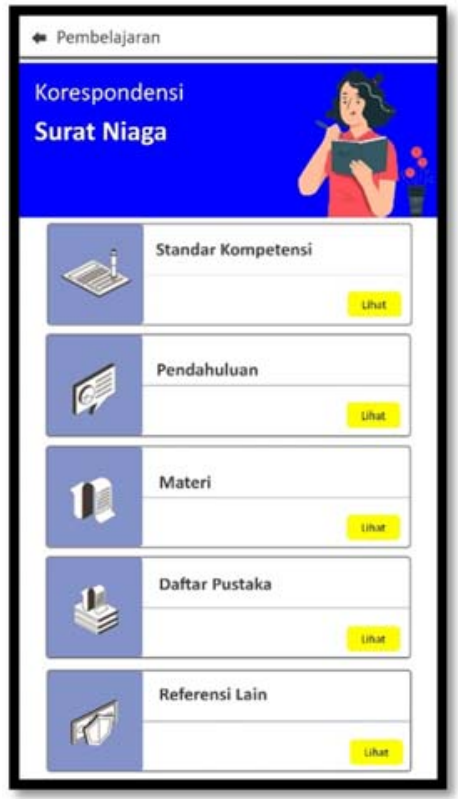

Gambar 2. Tampilan Menu Pembelajaran 
Selain ada menu pembelajaran juga terdapat menu Latihan soal dan soal evaluasi, yang dijadikan sebagai alat untuk mengukur hasil belajar peserta didik, adapun tampilannya adalah seperti pada gambar berikut ini.

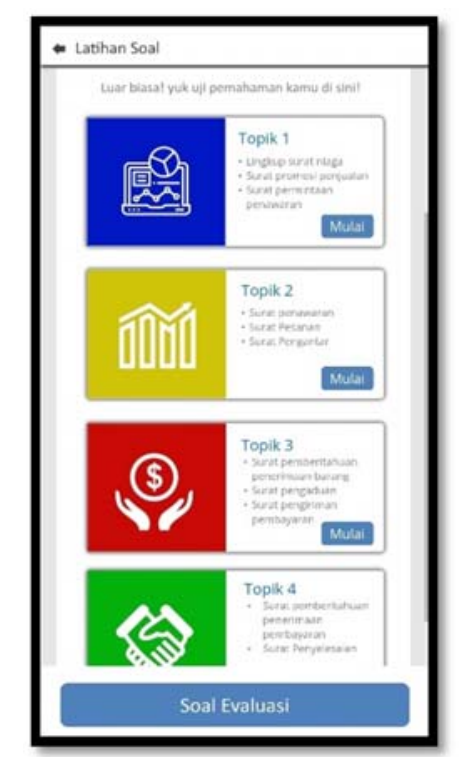

Gambar 5. Halaman Latihan Soal

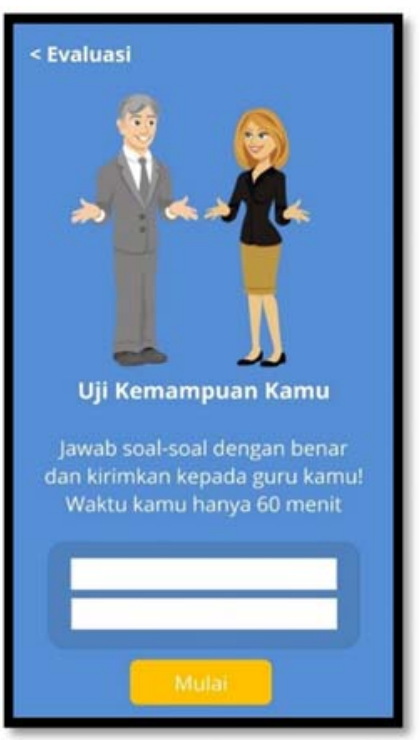

Gambar 4. Halaman Soal Evaluasi

Hasil validasi ahli materi, ahli media, dan peserta didik kelompok kecil terhadap media pembelajaran Me-Better disajikan pada Tabel 1 berikut ini

Tabel 1. Hasil Validasi Me-Better

\begin{tabular}{llll}
\hline No & Validasi & Persentase & Kriteria Validitas \\
\hline 1. & Ahli Materi & $100 \%$ & Valid \\
2. & Ahli Media & $95 \%$ & Valid \\
3. & Siswa Uji Coba Kelompok Kecil & $93 \%$ & Valid \\
& Rata-rata & $\mathbf{9 6 \%}$ & Valid \\
\hline
\end{tabular}

Sumber: Data hasil validasi Me-Better (2020)

Berdasarkan paparan data pada Tabel 1, diketahui rata-rata keseluruhan skor validasi yang diperoleh terhadap media pembelajaran Me-Better adalah sebesar 96\%, sehingga dapat ditarik kesimpulan bahwa media pembelajaran interaktif yang dikembangkan oleh peneliti yaitu Me-Better dinyatakan 'valid' dan layak untuk diimplementasikan sebagai media pembelajaran pada mata pelajaran korespondensi untuk kelas X Otomatisasi dan Tata Kelola Perkantoran di SMK Negeri 2 Selong. Hal ini selaras dengan penelitian sebelumnya yang dilakukan oleh Rahmawati and Mukminan (2018) hasil penelitian menunjukkan bahwa $M$ Learning yang dikembangkan menggunakan Adobe Flash Cs 5.5 untuk materi Hidrosfer dinilai memenuhi kriteria dinyatakan layak sebagai media pembelajaran dengan kategori baik.

Setelah media pembelajaran memperoleh penilaian valid dan layak, maka selanjutnya dilakukan uji coba pemakaian terhadap kelompok besar. Uji coba dilakukan terhadap peserta didik kelas X OTKP 2 yang berjumlah 27 orang. Uji coba ini dilakukan untuk mengetahui efektifitas penggunaan media pembelajaran Me-Better terhadap kemandirian belajar dan hasil belajar peserta didik. Pada Tabel 2 berikut ini disajikan data kemandirian belajar peserta didik 
baik pada kelas yang menggunakan media pembelajaran Me-Better maupun peserta didik yang tidak menggunakan Me-Better.

Tabel 2. Data Kemandirian Belajar

\begin{tabular}{lll}
\hline \multirow{2}{*}{ Aspek } & \multicolumn{2}{c}{ Persentase } \\
& $\begin{array}{l}\text { Kelas } \\
\text { Eksperimen }\end{array}$ & $\begin{array}{l}\text { Kelas } \\
\text { Kontrol }\end{array}$ \\
\hline Evaluasi diri (Self-evaluation) & $91 \%$ & $74 \%$ \\
Menetapkan tujuan dan perencanaan (goal setting and & & \\
planning) & $90 \%$ & $77 \%$ \\
Mencari informasi (seeking information) & $94 \%$ & $80 \%$ \\
Mengatur lingkungan (environment structuring) & $94 \%$ & $78 \%$ \\
Konsekuensi diri (self-consequences) & $95 \%$ & $70 \%$ \\
Mengulang dan mengingat (rehearsing and memorizing) & $78 \%$ & $79 \%$ \\
Mencari dukungan sosial (seeking social assistance) & $95 \%$ & $74 \%$ \\
Rata-Rata & $\mathbf{9 1 \%}$ & $\mathbf{7 6 \%}$ \\
\hline
\end{tabular}

Sumber: Kuesioner Kemandirian Belajar (2020)

Berdasarkan data kuesioner kemandirian belajar yang telah dipaparkan pada Tabel $2 \mathrm{di}$ atas, kelas eksperimen memiliki rata-rata skor kemandirian belajar sebesar 3.62 dengan ratarata persentase skor masing-masing aspek kemandirian belajar sebesar 91\% yang artinya dikategorikan ke dalam tingkat kemandirian belajar sangat tinggi, sedangkan untuk kelas kontrol memiliki rata-rata skor kemandirian belajar sebesar 3.02 dan rata-rata persentase skor masing-masing aspek kemandirian belajar sebesar 76\% yang artinya dikategorikan ke dalam tingkat kemandirian belajar tinggi. Dengan begitu dapat disimpulkan bahwa terdapat perbedaan yang signifikan antara kemandirian belajar peserta didik yang menggunakan media Me-Better dan peserta didik yang tidak menggunakan media Me-Better dengan beda persentase kurang lebih sebesar 15\%. Dengan begitu dapat disimpulkan penggunaan media pembelajaran interaktif Me-Better dapat meningkatkan kemandirian belajar peserta didik.

Peningkatan kemandirian belajar peserta didik ini tentunya tidak lepas dari sifat dari media pembelajaran Me-Better, Me-Better merupakan media pembelajaran yang dapat diinstall di smartphone peserta didik, sehingga fleksibel, peserta didik dapat melakukan pembelajaran kapan saja dan dimana saja. Peserta didik dapat melakukan self evaluation karena di dalam Me-Better sudah disediakan latihan soal dan juga soal evaluasi, evaluasi sendiri merupakan suatu kegiatan yang dilakukan dengan tujuan untuk mengetahui secara pasti mengenai keberhasilan belajar peserta didik (Luqman, 2017). Dengan menggunakan media pembelajaran Me-Better peserta didik dapat dengan mudah melakukan environment structuring yaitu menentukan tempat dan lingkungan belajar, lingkungan belajar yang baik adalah lingkungan yang dapat memberikan kenyamanan serta kepuasan sehingga dapat mencapai tujuan pembelajaran (Noviati dkk, 2019).

Selanjutnya pada Tabel 3 berikut ini dipaparkan mengenai data hasil belajar yang diperoleh oleh peserta didik yang menggunakan media pembelajaran Me-Better dengan peserta didik yang tidak menggunakan Me-Better. 
Tabel 3. Data Hasil Belajar

\begin{tabular}{lllll}
\hline $\begin{array}{l}\text { No. } \\
\text { Absen } \\
\text { Siswa }\end{array}$ & \multicolumn{2}{l}{ Kelas Eksperimen } & Kelas Kontrol & \\
\hline $\begin{array}{l}\text { Rata- } \\
\text { Rata }\end{array}$ & 80.18 & KKM (75) & Nilai & KKM (75) \\
\hline
\end{tabular}

Sumber: Data Hasil Belajar (2020)

Berdasarkan data hasil posttest yang disajikan pada Tabel 3 di atas, perhitungan ratarata hasil posttest peserta didik pada kelas eksperimen adalah sebesar 80.18 dengan ketercapaian KKM (75) sebesar 89\% dari 27 orang peserta didik atau terdapat 3 orang peserta didik yang nilainya di bawah KKM. Sedangkan perhitungan rata-rata hasil posttest pada peserta didik kelas kontrol adalah sebesar 71.72 dengan ketercapaian KKM(75) sebesar 48\% dari 29 orang peserta didik atau terdapat 14 orang peserta didik yang nilainya masih berada di bawah KKM. Dengan begitu dapat disimpulkan bahwa terdapat perbedaan yang signifikan antara hasil belajar peserta didik yang menggunakan media Me-Better dan peserta didik yang tidak menggunakan media Me-Better, atau dengan kata lain pengembangan media pembelajaran interaktif Me-Better dikatakan berhasil karena mampu mencapai ketuntasan belajar peserta didik di atas $75 \%$ yaitu $89 \%$.

\section{Simpulan}

Penelitian dan pengembangan ini menghasilkan produk berupa media pembelajaran interaktif berbasis android pada mata pelajaran Korespondensi KD 3.8 Menganalisis Surat Niaga dan KD 4.8 Membuat Surat Niaga untuk kelas X OTKP 2 di SMK Negeri 2 Selong, media pembelajaran ini diberi nama Me-Better (Mobile Education for Business Letter) yang dapat diunduh dengan cara memindai barcode ataupun mengakses link yang telah disediakan peneliti.

Berdasarkan hasil validasi yang dilakukan oleh 2 ahli, yaitu ahli materi dan ahli media serta setelah melewati uji coba terhadap kelompok kecil, didapatkan hasil bahwa media pembelajaran yang dikembangkan dinilai sangat layak untuk diimplementasikan sebagai media pembelajaran pada kegiatan pembelajaran.

Setelah dilakukan penelitian penggunaan media pembelajaran interaktif berbasis android bernama Me-Better, didapatkan hasil bahwa terdapat perbedaan kemandirian belajar dan hasil belajar peserta didik yang menggunakan media pembelajaran Me-Better dengan peserta didik yang tidak menggunakan media pembelajaran Me-Better. Peserta didik yang menggunakan Me-Better memiliki tingkat kemandirian belajar serta hasil belajar yang lebih tinggi dibandingkan dengan peserta didik yang tidak menggunakan Me-Better.

\section{Daftar Rujukan}

Dewi, W.A.F., (2020). Dampak COVID-19 terhadap Implementasi Pembelajaran Daring di Sekolah Dasar. EDUKATIF Jurnal Ilmu Pendidikan 2(1), 55-61. https://doi.org/10.31004/edukatif.v2i1.89

Ekayani, N.L.P., (2017). Pentingnya Penggunaan Media Pembelajaran Untuk Meningkatkan Prestasi Belajar Siswa Jurnal Fakultas Ilmu Pendidikan Universitas Pendidikan Ganesha Singaraja, 2(1), 1-11.

Luqman, A., (2017). Posisi Evaluasi Diri dalam Sistem Penjaminan Mutu Pendidikan Tinggi. Cendekia J. Education and Society 15, 37. https://doi.org/10.21154/cendekia.v15i2.987 
Jurnal Ekonomi, Bisnis dan Pendidikan, 1(5), 2021, 510-516

Noviati, R., Misdar, M., Adib, H.S., 2019. Pengaruh Lingkungan Belajar Terhadap Tingkat Konsentrasi Belajar Siswa Pada Mata Pelajaran Akidah Akhlak Di Man 2 Palembang. PAIRF 1, 1-20. https://doi.org/10.19109/pairf.v1i1.3010

Rahmawati, E.M., Mukminan, M., 2018. Pengembangang m-learning untuk mendukung kemandirian dan hasil belajar mata pelajaran Geografi. jitp 4, 157. https://doi.org/10.21831/jitp.v4i2.12726

Susilana, R., Riyana, C., 2009. Media Pembelajaran: Hakikat, Pengembangan,Pemanfaatan,dan Penilaian. CV Wacana Prima, Bandung.

Yahya, R., 2020. Pengembangan Perangkat Pembelajaran Flipped Classroom Bercirikan Mini-Project Supremum Journal of Mathematics Education, 4(1), 78-91. 